\title{
Effects of Acute Ammonium Nitrate Levels Caused by Agricultural Activities on Four Amphibian Species in The Eastern Black Sea Region ${ }^{\#}$
}

\author{
Handan Karaoğlu ${ }^{1, a, *}$ \\ ${ }^{I}$ Department of Field Crops, Faculty of Agriculture, Recep Tayyip Erdoğan University, 53100 Rize, Turkey \\ *Corresponding author \\ A R T I C L E I N F O \\ ${ }^{\#}$ This study was presented as an online \\ presentation at the $2^{\text {nd }}$ International \\ Journal of Agriculture - Food Science \\ and Technology (TURJAF 2021) \\ Gazimă̆usa/Cyprus \\ Research Article \\ Received : 15/12/2021 \\ Accepted : 01/01/2022 \\ Keywords: \\ Acute ammonium \\ Pelophylax ridibundus \\ Rana macrocnemis \\ Pelodytes caucasicus \\ Bufotes variabilis

\section{A B S T R A C T} \\ The tadpoles of four amphibian species, namely the Marsh Frog (Pelophylax ridibundus), the \\ Iranian Long-Legged Frog (Rana macrocnemis), the Caucasian Parsley Frog (Pelodytes \\ caucasicus) and the Variable Green Toad (Bufotes variabilis), were exposed to acute concentrations \\ ( 0 to $500 \mathrm{mg} / \mathrm{L}$ ) of ammonium nitrate to assess the lethal effects (larval growth, abnormalities, \\ mortality, and $\mathrm{LC}_{50}$ values). Eggs of each species were obtained from clean and polluted habitats in \\ the same region and the tadpoles for experiments were provided from those eggs in the laboratory \\ conditions. Although there was some variability between different populations of the same species \\ or between different species in the observed effects, acute levels of ammonium nitrate caused \\ decreased growth rate and increased abnormalities and mortality in general. Among the 4 amphibian \\ species, the Variable Green Toad was the most damaged one in terms of growth reduction (on \\ average $77-83 \%$ ), and abnormality rates, and the most damaged one in terms of mortality rates was \\ the Marsh Frog (on average 61-72\%). Additionally, the species with the lowest concentration of \\ ammonium nitrate, which killed half of its population, was the Marsh Frog. LC 50 values for two \\ populations of Marsh Frog were 37 and $59 \mathrm{mg} / \mathrm{L}$. As a result of our research, it was determined that \\ the acute fertilizer levels caused by agricultural activities in the region had very important harmful \\ effects for all the species we examined. In this context, it can be said that very important \\ environmental and biodiversity problems may occur if certain precautions are not taken regarding \\ the use of the fertilizers and if the awareness of the farmers using these fertilizers cannot be raised.
}

handan.karaoglu@erdogan.edu.tr@iDttps://orcid.org/0000-0001-6838-1856|

\section{Introduction}

Nowadays, many species have been going extinct and their populations have been declining because of human activities and it is thought that there will be any changes about these activities in the next century (Pimm et al., 2014; Pimm and Raven, 2000; Sala et al., 2000). Anthropogenic habitat loss is defined as a primary danger for $85 \%$ of all species, which have been classified as threatened by the IUCN Red List (IUCN, 2015). Moreover, present extinction rate is 100 and 1000 times higher than the extinction rate ever known, which represents the biggest extinction rate over the last 65 million years (Ceballos et al., 2015). The human-related activities decrease diversity of ecosystem and eventually cause widely impoverishment of functional ecosystem diversity, functioning, and imperiling many ecosystem services (Flynn et al., 2009; Jantz et al., 2014; Newbold et al., 2015).
Ever-increasing human population and needs for the resources cause significant changes on the Earth. According to the data, approximately $53 \%$ of the Earth have been modified by human activities up to now (Hooke et al., 2012). In addition, these activities accelerate conversion and loss of coastal and continental wetlands have globally almost halved (Davidson, 2014).

Worldwide, particular human activities have particular effects on biodiversity. For example, urbanization and agriculture represent powerful biotic homogenization factors. These factors exhibit negative effects on abundance of population and community richness of vertebrate species, and thus oversimplify habitats (Gagn'e and Fahrig, 2007; Hodgkison et al., 2007; Ordenana et al., 2010; Suazo-Ortuno et al., 2008). In a similar way, deforestation performed by human beings, fragmentation and isolation of natural habitats originate negative impacts on population dynamics and community composition of 
vertebrate (Kutt et al., 2012; Scott et al., 2006). However, the other human-related activities exhibited complicated response patterns on vertebrate species. For example, certain vertebrate species can be affected in a negative manner because of activities such as cattle raising (BadilloSaldana et al., 2016; Popescu et al., 2012).

It was known that amphibians and reptiles are the most susceptible groups to the changes caused by human beings among vertebrates (Barrett and Guyer, 2008; Wake and Vredenburg, 2008). Practically, amphibians and reptiles possess considerably higher of threatened species than birds or mammals (IUCN, 2020; Nori et al., 2015). Nonetheless, these two groups (amphibians and reptiles) exhibit mainly similar responses against environmental changes, although there is significant variability among species within these two groups against changes. Hereby, it can be observed positive or negative effects on richness and abundance of herpetofauna species depending on the disturbance type (Adum et al., 2013; Cano and Leynaud, 2010; Guerra and Aráoz, 2015). In recent decades, the extinction rate of amphibians worldwide has exceeded the historic background extinction rate at least by 200 folds (Roelants et al. 2007). Considering all these factors, it poses a challenging task to draw an overall conclusion about how anthropogenic land-use changes affect herpetofaunal communities. Partly, this situation can be observed in previous studies about the overall effects of land-use changes on the abundance or richness of amphibians and reptiles (Gardner et al., 2007; Thompson et al., 2016; Scheffers and Paszkowski, 2013).

Amphibians are the most threatened one among the vertebrate classes of the world with rate of

$41 \%$ and agriculture is the most important and widespread threat among the reasons threaten amphibians (IUCN 2021; Harfoot et al., 2021). According to the IUCN (2021) data set, approximately 37 amphibian species have gone globally extinct and many of them were endemic to those particular regions they were found in and 663 species are considered "Critically Endangered", 1060 are "Endangered", 721 are "Vulnerable", and 421 are "Near Threatened" (IUCN 2021). Near the half of the 7215 observed species are declining in population size, which suggests that in the future more species will either become extinct or enter higher Red List categories (Beebee and Griffiths 2005, Sodhi et al. 2008). Furthermore, among the threats to amphibians agriculture is the most widely and the most important reason threaten amphibians (IUCN 2021; Harfoot et al., 2021).

Eventually, the most serious activity of humans is agricultural expansion resulting in "habitat loss" and damaging amphibian populations while considering amphibian population decrease (Gallant et al., 2007; Cordier et al., 2021). Agriculture and and agricultural applications are the main reasons for natural ecosystem loss and/or fragmentation (Powell and Lenton, 2013; Hana cek and Rodríguez-Labajos, 2018).

Amphibian populations are frequently endangered by barriers to connectivity and alien competitors, pathogens, predators, and thermal shifts. (Shuman-Goodier et al., 2017; Pounds et al., 2006; Falaschi et al., 2020; Alford et al., 2007). To be susceptible to contamination because of their semi-permeable skins is another disadvantage of amphibians (Egea-Serrano et al., 2012; Slaby et al., 2019).
The other major threating factors on amphibian populations are fertilizers and other agrochemicals such as nitrogenous compounds (Krishnamurthy and Smith, 2010;2011; Trudeau et al., 2020; Van Meter et al., 2019; Marco and Ortiz-Santaliestra, 2009; Baker et al., 2013). As a result, the most extensive human activity is agricultural activities that result in 'habitat loss' for amphibian populations and contribute to their gradual decline (Gallant et al., 2007; Cordier et al., 2021).

The rapid population growth in the world has brought an increasing need for food, and in order to meet this need, an increase in agricultural production has begun to be needed. In this context, efforts are being made to answer the increasing food demand through the use of more efficient resources and the adoption of production systems in which various fertilizers are applied for various plants (Polat, 2018). As is the case in the Eastern Black Sea Region, nitrogenous fertilizers have been used at values exceeding the need in order to increase the efficiency of agricultural products, and in this case, excess fertilizer is washed from the soil and seeps into water resources, creating nitrogen pollution that causes significant damage to aquatic organisms and environmental health (Mohsenipour et al., 2014).

The results obtained from the researches carried out in various rivers belonging to the Eastern Black Sea Region showed that the pollution values such as nitrite, nitrate, ammonia, phosphate and sulfate increased as these rivers approach the sea and especially the rivers were polluted or very polluted water bodies at a level that threatened health in terms of nitrate, nitrite ammonia parameters (Day1 1996; Özdemir 1998; Boran et al., 2001; Bulut 2005; Gültekin et al., 2005; Gültekin et al., 2012).

Since the most intensively applied fertilizers in the world $(87 \%)$ and in Turkey $(68 \%)$ are nitrogen fertilizers such as ammonium nitrate (FAO, 2021) and their lethal effects on the species distributed in the region and selected for the study are not comprehensively known, the current study was planned to contribute to the conservation of biodiversity by eliminating this deficiency. The study time was not limited to 96 hours like most studies nowadays because water analysis showed that high nitrate concentrations were seen in the study areas for longer.

\section{Methods}

\section{Study Sites and Species}

Physical and water chemistry characteristics of the study sites were summarized in Table 1. Also, the characteristics of the species studied were summarized in Table 2.

\section{Acute Experiment}

For all species, at least 5 egg clutches were collected from naturel and polluted habitats that were selected according to the results of the water analysis. To obtain the tadpoles from eggs hatched to the laboratory, incubation containers were used ventilated continuously, kept in natural photoperiod, and at $20-21^{\circ} \mathrm{C}$ temperature. The experiments were started by selecting healthy and equal sized tadpoles reached 25th developmental stage. 
Table 1. Physical and water chemistry characteristics of the study sites

\begin{tabular}{|c|c|c|c|c|c|c|c|c|}
\hline \multirow{3}{*}{$\begin{array}{l}\text { Habitat } \\
\mathrm{pH}\end{array}$} & \multicolumn{2}{|c|}{$\begin{array}{l}\text { Marsh } \\
\text { Frog }\end{array}$} & \multicolumn{2}{|c|}{ Iranian Long-Legged Frog } & \multicolumn{2}{|c|}{ Caucasian Parsley Frog } & \multicolumn{2}{|c|}{$\begin{array}{c}\text { Variable Green } \\
\text { Frog } \\
\end{array}$} \\
\hline & Değirmendere & Söğg̈tlü & Uzungöl & Adacik & Uzungöl & Hidırnebi & Seyitler & Adacık \\
\hline & 8.31 & 8.21 & 7.6 & 7. & 7. & 8 & 7.52 & 6 \\
\hline WT & $20-21^{\circ} \mathrm{C}$ & $20-21^{\circ} \mathrm{C}$ & $15-17^{\circ} \mathrm{C}$ & $19-20^{\circ} \mathrm{C}$ & $16-18^{\circ} \mathrm{C}$ & $14-16^{\circ} \mathrm{C}$ & $18-20^{\circ} \mathrm{C}$ & $17-19^{\circ} \mathrm{C}$ \\
\hline Alt & $14 \mathrm{~m}$ & $9 \mathrm{~m}$ & $1138 \mathrm{~m}$ & $68 \mathrm{~m}$ & 110 & 16 & $550 \mathrm{~m}$ & $17 \mathrm{~m}$ \\
\hline $\mathrm{Ni}$ & 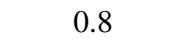 & 15 & 10 & 8 & 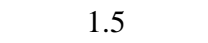 & 1 & 1.2 & 84 \\
\hline Nitrit & 0.008 & 0.09 & 0.027 & 0.36 & 0.0 & 0 . & 0.016 & 0.39 \\
\hline Ammonium & $<2.6$ & $<2.6$ & $<2.6$ & 3.0 & $<2.6$ & $<2.6$ & $<2.6$ & 3.1 \\
\hline \multirow{2}{*}{ Coordinate } & $40^{\circ} 59^{\prime} 45^{\prime \prime} \mathrm{N}$ & $41^{\circ} 00^{\prime} 1 " \mathrm{~N}$ & $40^{\circ} 37^{\prime} 04^{\prime \prime} \mathrm{N}$ & $41^{\circ} 00^{\prime} 43^{\prime \prime} \mathrm{N}$ & $40^{\circ} 57^{\prime} 27.83^{\prime \prime} \mathrm{N}$. & $40^{\circ} 36^{\prime} 44.33^{\prime \prime} \mathrm{N}$ & $41^{\circ} 11^{\prime} 42^{\prime \prime} \mathrm{N}$ & $41^{\circ} 01^{\prime} 13^{\prime \prime} \mathrm{N}$. \\
\hline & 39'46'1 8"E & 39'37'46"E & $40^{\circ} 17^{\prime} 53 " \mathrm{E}$ & $39^{\circ} 33^{\prime} 48^{\prime \prime} \mathrm{E}$ & $39^{\circ} 26^{\prime} 1.27^{\prime \prime E}$ & $40^{\circ} 18^{\prime} 42.53^{\prime \prime} \mathrm{E}$ & $41^{\circ} 50^{\prime} 44^{\prime \prime} \mathrm{E}$ & $39^{\circ} 34^{\prime} 39^{\prime \prime} \mathrm{E}$ \\
\hline DD & $0.5 \times 2.7$ & $0.4 \times 2.4$ & $0.26 \times 4.1$ & $0.7 \times 3.6$ & $2 \times 5$ & $1-2 \times 3-5$ & $0.31 \times 2.9$ & $0.7 \times 3.6$ \\
\hline
\end{tabular}

WT: Water Temperature, DD: Max. depth and diameter

Table 2. Characteristics of the species studied

\begin{tabular}{|c|c|c|c|c|c|}
\hline & $\begin{array}{c}\text { Conversation } \\
\text { Status }\end{array}$ & $\begin{array}{c}\text { Population } \\
\text { Status }\end{array}$ & Characteristics & Threats & Distribution \\
\hline Mars Frog & Least Concern & Increasing & Edible & $\begin{array}{l}\text { Over- harvesting } \\
\text { Agricultural } \\
\text { Pollution }\end{array}$ & Wide \\
\hline $\begin{array}{l}\text { Iranian Long- } \\
\text { Legged Frog }\end{array}$ & Least Concern & Decreasing & $\begin{array}{l}\text { It took its Turkish name } \\
\text { from Uludağ. }\end{array}$ & $\begin{array}{l}\text { Habitat Loss } \\
\text { Agricultural } \\
\text { Pollution }\end{array}$ & Medium \\
\hline $\begin{array}{l}\text { Caucasian } \\
\text { Parsley Frog }\end{array}$ & $\begin{array}{l}\text { Near } \\
\text { Threatened }\end{array}$ & Decreasing & $\begin{array}{l}\text { Endemic } \\
\text { Larval hibernation } \\
\text { Nocturnal }\end{array}$ & $\begin{array}{l}\text { Agricultural } \\
\text { Pollution }\end{array}$ & Narrow \\
\hline $\begin{array}{l}\text { Variable Green } \\
\text { Toad }\end{array}$ & Data Deficient & Decreasing & Nocturnal & $\begin{array}{l}\text { Agricultural } \\
\text { Pollution }\end{array}$ & Medium \\
\hline
\end{tabular}

For investigating the acute effects of ammonium nitrate $\left(\mathrm{NH}_{4} \mathrm{NO}_{3}\right.$; Millipore Sigma 6484-52-2, ACS reagent, granular purity $98 \%$ ) on the laboratory-hatched tadpoles of all the four species from each pond, four replicates of six G25 tadpoles were exposed to each of seven different $\mathrm{NH}_{4} \mathrm{NO}_{3}$ concentrations $(0,50,75,100,250,350,500$ $\mathrm{mg} / \mathrm{L}$ ) for 15 days. $5 \mathrm{~L}$ opaque plastic containers having 2 L aerated RSW $\left(2461^{\circ} \mathrm{C}\right)$ were used for every replicate. Totally, $28(7 \times 4)$ containers and $168(7 \times 4 \times 6)$ tadpoles were used in the acute experiment for each habitat. To keep $\mathrm{pH}$ at 7.5 , TRIS-buffer $(10 \mathrm{mM})$ was added to all solutions. Test solutions were renewed every day. The tadpoles were fed daily with boiled lettuce and checked to count dead or abnormal tadpoles. Dead tadpoles were removed two times a day. The experiments were performed under the same conditions for all the species and of all tadpoles were measured at the same way (Hecnar 1995; Johansson et al., 2001)

\section{Statistical analyses}

The nonparametric Kruskal Wallis, Mann-Whitney U, and Chi-Square tests included in the SPSS 22.0 (Statistical Package for Social Science) package program were used to determine whether there was a difference between the growth rates, abnormality rates, mortality rates, and completion time of metamorphosis in the applied experiments. used. Also, Probit analysis (Finney Method [Lognormal Distribution]) included in the StatPlus package program was used to determine the concentration of ammonium nitrate to cause of kill fifty percent of the larval population ( $\mathrm{LC}_{50} 15$ days).

\section{Results}

When the experiments ended, the acute effects of ammonium nitrate were growth reduction, some abnormalities, and mortalities at a certain degree. Although there were fluctuations in harmful effects among different species or populations, it was founded that these effects reached a greater level for the natural habitat populations than for the agricultural one. Throughout the experiments, it was determined that no adverse effects did not appear in the control groups in spite of, the adverse effects observed in the treatment groups occurred at significantly greater levels $(\mathrm{P}<0.05)$ than the control groups.

\section{Decrease in Growth Rates}

The decrease in weight gain was significantly greater for the natural habitat of Marsh Frog population than for the polluted one $(\mathrm{P}<0.05)$. When compared to the control group, it was determined that the decreasing in weight gain for the treatment groups ranged between $38-102 \%$ (average $70 \%$ ) for the agricultural habitat and it was ranged between $50-114 \%$ (average $80 \%$ ) for the natural one. (Figure 1-A).

For Iranian Long-Legged Frog, in treatment groups of both populations had significantly lower growth rates compared to the control group $(\mathrm{P}<0.05)$. However, the growth rates for the treatment groups of the two populations were found quite similar $(\mathrm{P}>0.05)$. The decreasing in value of growth rates for clean habitat varied between $67-72 \%$ (average 70\%) while the values of other varied between $74 \%$ - 75\% (average 75\%) similarly $(\mathrm{P}>0.05)$. (Figure 1-B). 

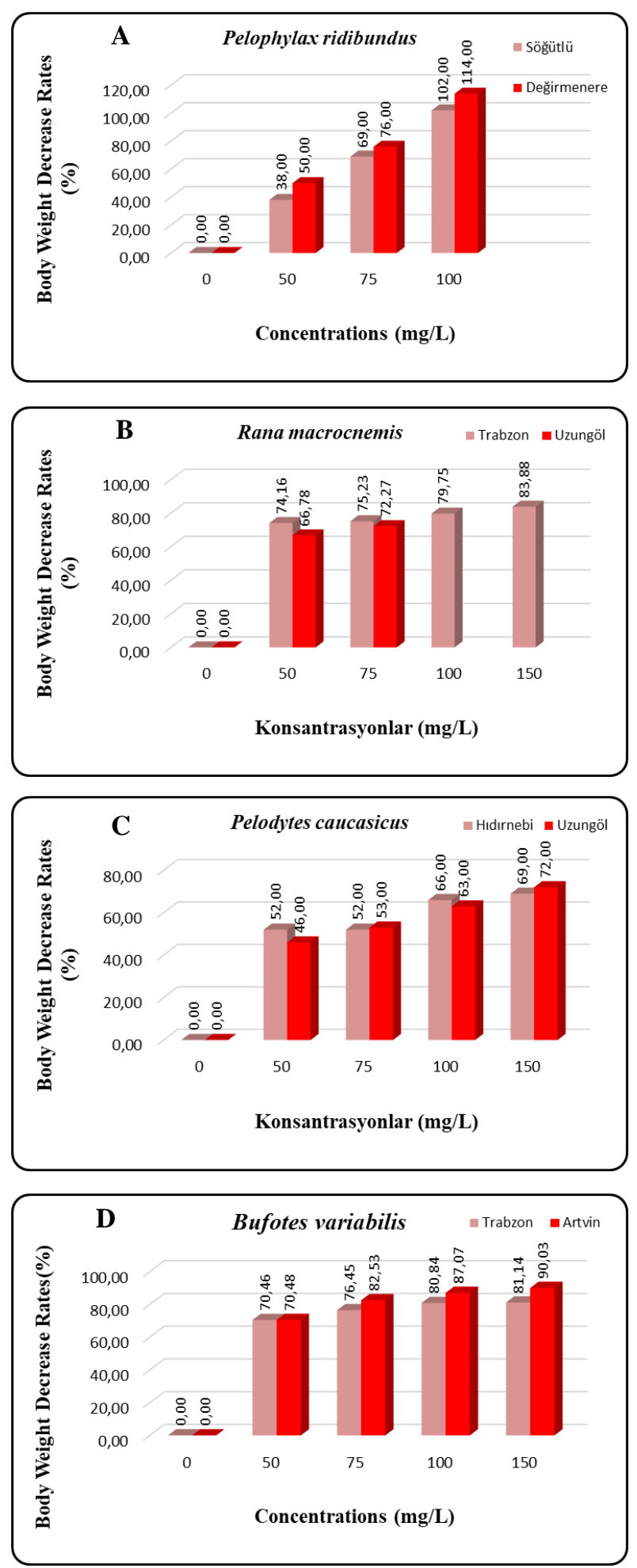

Figure 1. Values of Decrease in Growth.

The red bars represent the values of natural habitat tadpoles and the pink bars represent the values of polluted habitat tadpoles. Each bar represents the avarage values. A) Pelophylax ridibundus, B) Rana macrocnemis, C) Pelodytes caucasicus, D) Bufotes variabilis.

it was determined that Caucasian Parsley Frog tadpoles of all the treatment groups in both populations had significantly lower growth rate compared to the tadpoles of the control group $(\mathrm{P}<0.001)$. In addition, it was founded that the growth in the both populations the tadpoles belong low concentration groups were significantly higher growth rates than the tadpoles belong high concentration groups $(\mathrm{P}=0.01-0.05)$. (Figure 1-C).
Artvin population of the Variable Green Toad belonging to the clean region, it was detected that the weight decrease values ranged between 71-90\% (average $83 \%$ ). and for the Trabzon population, which belongs to the agricultural pollution region, the weight decrease values were found varying between $71-81 \%$ (average $77 \%$ ). The negative effects of ammonium nitrate on growth for the both populations were significantly similar, although the effects were more severe in the clean region population $(\mathrm{P}>0.05)$. (Figure 1-D).

Among the 4 amphibian species examined, the Variable Green Toad was the most damaged one in terms of growth reduction.

\section{Abnormalities}

Throughout the experiment, any abnormality was not detected in the control group tadpoles any species studied. But for all exposure group tadpoles of four species there were high level abnormalities compared the control groups such as decrease in feeding, slowing and disequilibrium in swimming, reduction in development, defect in body shape, edemas, tumors, loss of pigmentation, skewness of tail or body and paralysis.

For Marsh Frog, although the difference between the two populations was not statistically significant, abnormality rate for clean habitat tadpoles was higher than for the polluted one all treatment groups $(\mathrm{P}>0.05)$.

While the abnormalities occurring for the Iranian LongLegged Frog tadpoles were similar and high in all treatment groups in the clean habitat $(\mathrm{P}>0.05)$, high concentration groups of polluted habitats had significantly higher rates of abnormalities than that of the low concentration groups $(\mathrm{P}<0.05)$.

It was determined that, most of the abnormalities were occurred for the clean habitat of Caucasian Parsley Frog significantly higher rates than for the polluted habitat $(\mathrm{P}<0.05)$. Abnormality cases for natural habitat of the Variable Green Toad occurred at a higher level $(\mathrm{P}>0.05)$ compared the control groups and the polluted habitat in all treatment groups regardless of concentration. Some abnormal tadpole samples can be seen in Figure 2 (A-J).

\section{Mortality Rates and $\mathrm{LC}_{50}$ Values}

When the experiments finished, it was defined that generally there were no mortalities in any control groups while there were mortalities at certain rates in all exposure groups of all the species examined. When the mortality rates of clean and polluted habitat populations were compared, it was observed that mortality rates of clean habitat tadpoles were higher than the rates of polluted habitat tadpoles for all species examined.

For Marsh Frog, research results were indicated that the mortality rates of the 50,75 and $100 \mathrm{mg} / \mathrm{L}$ groups of the Değirmendere population varied between $67-83 \%$ (average $72 \%$ ), while the mortality rates of the Sögütlü population belonged to polluted habitat varied between 50-75\% (average 61\%). According to the results of the Probit analysis performed at the end of the 15-day acute experiment, $\mathrm{NH}_{4} \mathrm{NO}_{3}$ caused to kill fifty percentage of the tadpoles (LC50) was 1.56 times higher for the polluted habitat $(58.9 \mathrm{mg} / \mathrm{L})$ than for the clean habitat $(37.0 \mathrm{mg} / \mathrm{L})$. (Figure 4-A). 

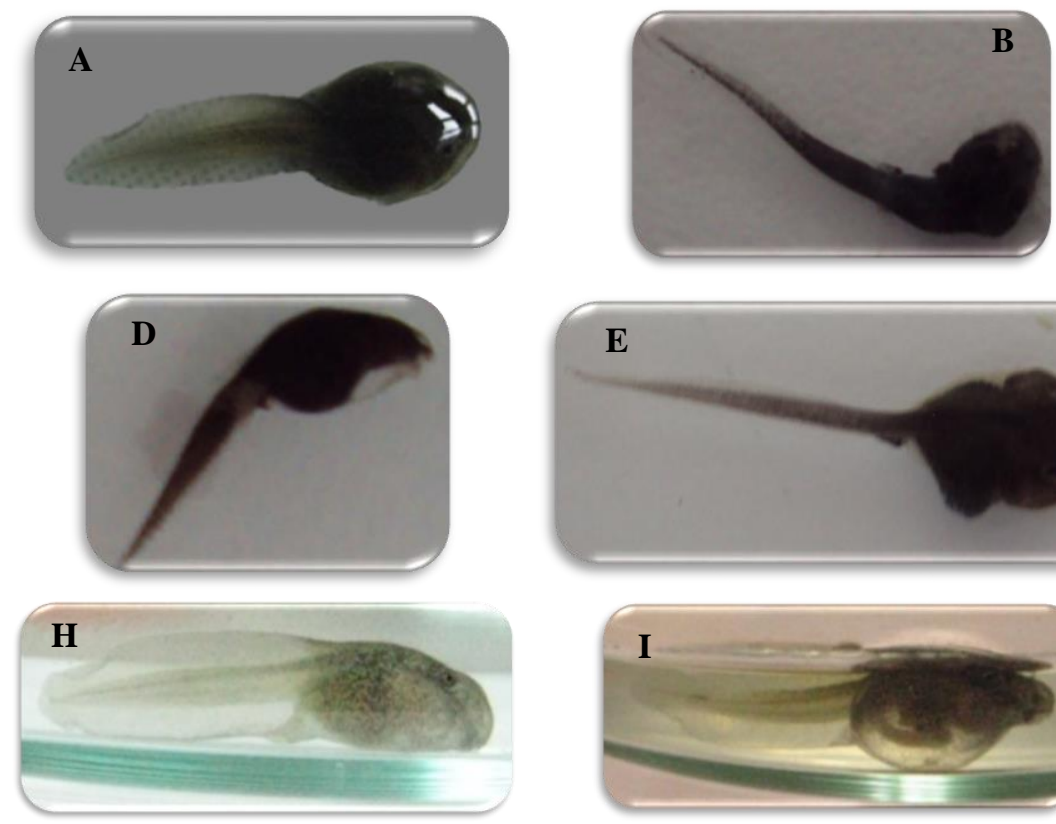
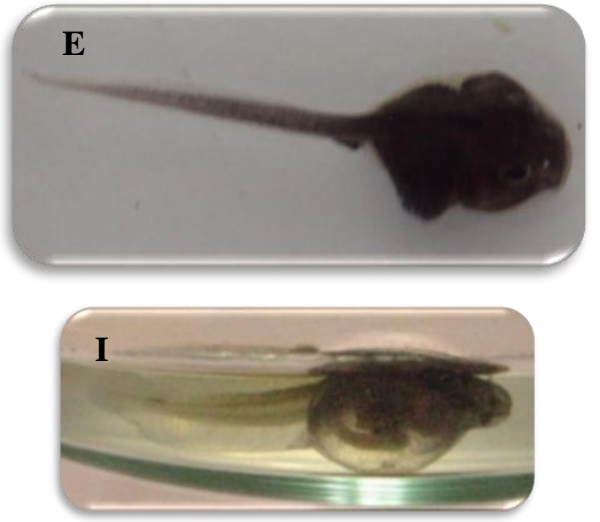
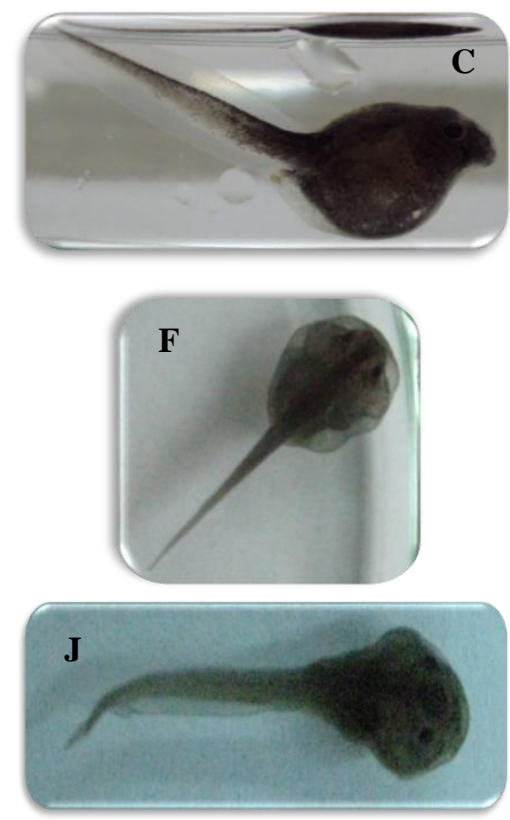

Figure 2. A) Sample of normal tadpole, B) Sample of tumor, weak development, skewness, C) Sample of lordosis and edema, D) Sample of lordosis and loss of pigmentation, E) Sample of tumor, F) Sample of loss of pigmentation, deterioration in body shape H) Sample of normal tadpole, I) Sample of edema, loss of pigmentation J) Sample of weak development, deterioration in body shape
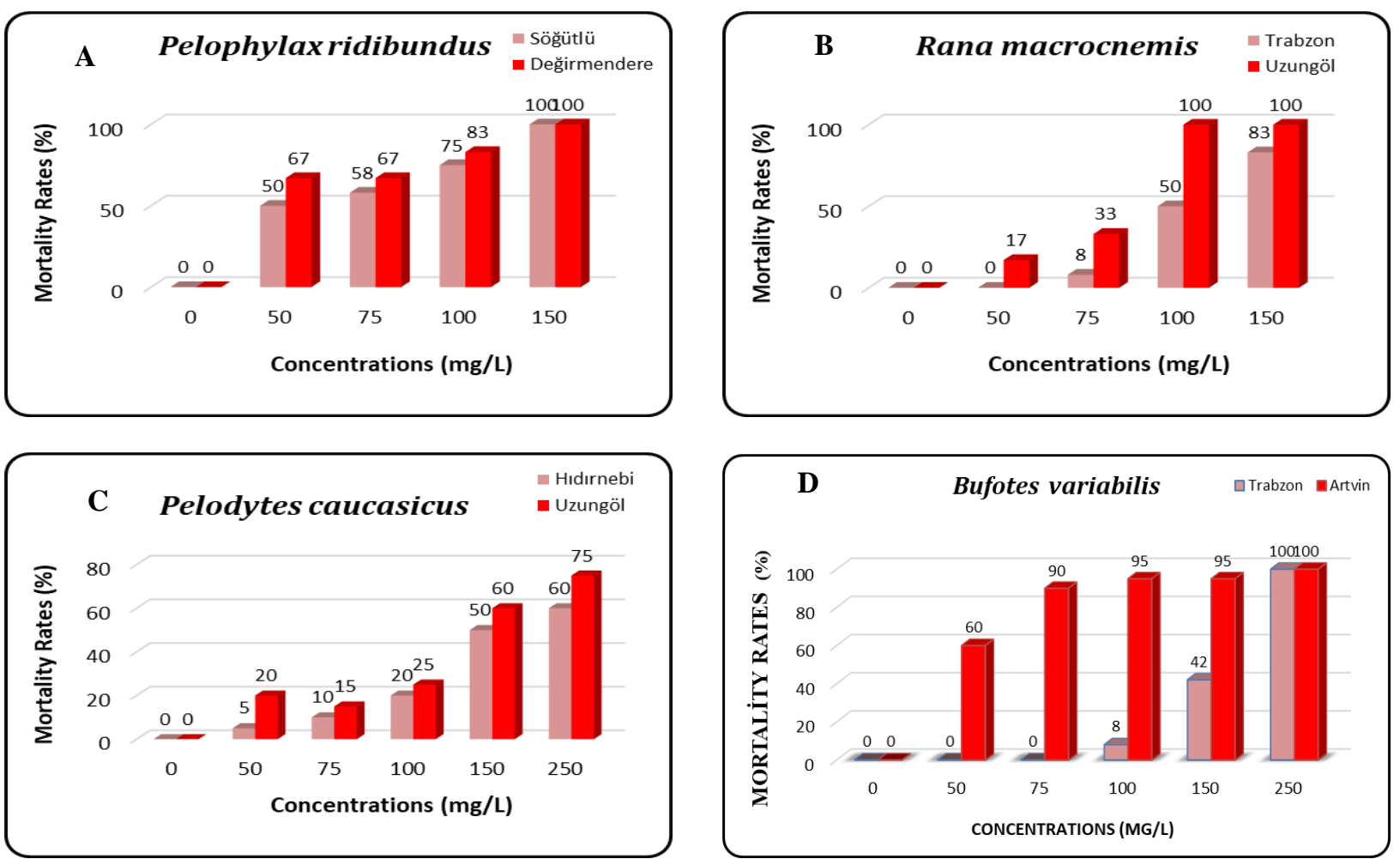

Figure 4. Values of Mortality Rates.

The red bars represent the values of natural habitat tadpoles and the pink bars represent the values of polluted habitat tadpoles. Each bar represents the avarage values. A) Pelophylax ridibundus, B) Rana macrocnemis, C) Pelodytes caucasicus, D) Bufotes variabilis.

Mortality rates of the Iranian Long-Legged Frog were found significantly higher for the clean habitat compared to the polluted one $(\mathrm{P}<0.05)$. It was founded that the mortality values for the application groups of the clean habitat varied between 17-100\% (average 63\%), and it varied between $0-83 \%$ (average $35 \%$ ) for the polluted habitat. (Figure 4-B).
In the treatment groups of Caucasian Parsley Frog, clean habitat mortality rates (except $500 \mathrm{mg} / \mathrm{L}$ ), occurred between $15-75 \%$ (average $39 \%$ ) and it varied between 5 $60 \%$ (average 29\%) in the polluted habitat (except 500 $\mathrm{mg} / \mathrm{L}$ ). According to the Probit analysis data made after 15 days of acute application, ammonium nitrate concentrations that will cause the death of half of the 
population are $170 \mathrm{mg} / \mathrm{L}$ for clean habitat. But it was 204 $\mathrm{mg} / \mathrm{L}$ for the polluted one. (Figure 4-C).

Mortality rates in all treatment groups of the Variable Green Toad were found significantly higher in the clean habitat compared to the polluted one $(\mathrm{P}<0.001)$. For the population living in the natural habitat, the treatment group mortality rates varied between $60-95 \%$, while the polluted habitat mortality rates varied between $0-42 \%$ (average $25 \%$ ). And $\mathrm{LC}_{50}$ value for the clean habitat was $46 \mathrm{mg} / \mathrm{L}$, while the value was $155 \mathrm{mg} / \mathrm{L}$ for the polluted one. Also, the $\mathrm{LC}_{50}$ value of the polluted population was 3,4 times higher. (Figure 4-D).

Among the 4 amphibian species the most damaged one in terms of mortality rates was the Marsh Frog (on average 61-72\%).

\section{Discussion}

Acute ammonium nitrate concentrations caused severe growth retardation, morphological and physiological abnormalities, and high mortality rates in all studied species.

Growth reduction averages were significantly high in all species (average 70-80\%) and were similar in both populations at 14 days. Growth reduction rates for $P$. caucasicus and $R$. macrocnemis were similar and they were more tolerant to ammonium nitrate than that having similar growth retardation $B$. variabilis and $P$. ridibundus.

Anaxyrus terestris at G25 developmental stage when exposed to $30 \mathrm{mg}$ of $\mathrm{N}$-nitrate for 15 days detected didn't exhibits any mortality (Edwards et.al., 2006). But Litoria caerulea exhibit 50\% mortality when exposed to $9 \mathrm{mg} / \mathrm{L}$ $\mathrm{N}$-nitrate for 16 days (Baker and Waights, 1994). On the other hand, Garriga et al. (2017) determined that when Alytes obstetricans exposed tadpoles to sodium nitrate and ammonium nitrite for 14 days, only ammonium concentrations above $56 \mathrm{mg} / \mathrm{L}$ caused lethal effects at the end of the experiment. They detected that tadpole growth was significantly reduced at ammonium concentrations above $34 \mathrm{mg} / \mathrm{L}$ and nitrate concentrations above $80 \mathrm{mg} / \mathrm{L}$. Similarly, in the current study for all the populations exposed to $50 \mathrm{mg} / \mathrm{L}$ ammonium nitrate concentrations, an average of 59\% reduction in growth was found in 15 days. In addition, $50 \mathrm{mg} / \mathrm{L}$ ammonium nitrate caused $27 \%$ mortality in all populations. Only agricultural habitat populations of $R$. macrocnemis and B. variabilis did not demonstrate mortality. On the other hand, when Hypsiboas faber tadpoles were exposed to $10 \mathrm{mg} / \mathrm{L}$ ammonium sulfate for 21 days, it was determined that the activity level decreased and $21 \%$ mortality occurred (Ilha and Schiesari, 2014). Also; In the study in which $58 \mathrm{mg} / \mathrm{L}$ ammonium nitrate was applied to Pelobates cultripes and Discoglossus galganoi tadpoles for 12 days, mortality rates were determined as low as approximately $10 \%$ and $20 \%$, respectively. (Ortiz-Santaliestra et al, 2006). On the other hand, when Lithobates clamitans and L. catesbeianus were exposed to different sodium nitrate concentrations, tadpoles did not exhibit reducing body mass (Smith et al., 2005). But in the case of Alytes obstetricans, Garriga et al. (2017) detected a growth decreasing for $80 \mathrm{mg} / \mathrm{L}$ nitrate at 14 days of an experiment but the tadpoles didn't expose reduced growth when they applied $2,5 \mathrm{mg} / \mathrm{L}$ nitrate. In the light of the results, it was understood that nitrate was much less toxic than ammonium, while current research results showed that there was a difference between species in ammonium nitrate resistance, similar to other research results. (Karaoglu, 2011; Karaoglu et al., 2010; Mann et al., 2009; Egea-Serrano et al., 2012).

Ortiz-Santaliestra et al. $(2004 ; 2006)$ investigated the effects of ammonium nitrate on Epidalea calamita and Bufo spinosus that are extinct today. 58 and $145 \mathrm{mg} / \mathrm{L}$ ammonium nitrate cause $40 \%$ and $65 \%$ mortality. They also studied about the same concentration for 12 days on Pelobates cultripes that extinct also. The embryos exposed $58 \mathrm{mg} / \mathrm{L}$ ammonium nitrate exhibit $70 \%$ mortality. Similar to this data, in the current research mortality rates at 50 and $150 \mathrm{mg} / \mathrm{L}$ ammonium nitrate for all the populations range between $27 \%$ and $79 \%$. According to the results of water pollution analyses, there is extraordinary nitrogen pollution in the 3 extinct amphibian's habitats nowadays with 20 $\mathrm{mg} / \mathrm{L}$ nitrate and $40 \mathrm{mg} / \mathrm{L}$ ammonium. While there is such a high level of ammonium pollution, which is known to affect the nervous and muscular systems in particular (McKenzie et al., 2009), it has been concluded that there is no need to look for any other reason for the extinction of these 3 amphibian species.

In a recent study, observed abnormalities were similar to Hecnar (1995), Xu and Oldham (1997), Karaoglu et al. (2010), and Karaoglu (2011) (decrease in feeding, slowing and disequilibrium in swimming, reduction in development, defect in body shape, edemas, tumors, loss of pigmentation, skewness of tail or body and paralysis) and occurred at high levels in both populations of each species studied, since the concentrations of chemical pollutant were highly elevated.

The non-lethal effects of agricultural pollutants impair the escape velocity and predator detection ability of amphibians, making them more susceptible to predation (McKenzie et al., 2009; Ortiz-Santaliestra et al, 2010). There are two possible reasons for this: because nitrate compounds reduce oxygen-carrying capacity in animals, animals exposed to these compounds are often lethargic (Gomez Isaza et al., 2018; Monsees et al., 2017). And also, ammonium ion affects the nervous and muscular systems of vertebrates and therefore restricts mobility (McKenzie et al., 2009). Therefore, amphibians exposed to agricultural pollution spend less time looking for mates, feeding, and protecting their territories. When the foraging tendency weakens, development slows down (Werner and Anhold, 1993). There are also studies proving that tadpoles that are faster swimmers: have a higher chance of surviving prey attacks by fish, turtles, dragonfly larvae, snakes, and other tadpoles (Teplitsky et al., 2005; (Feder, 1983; Chovanec, 1992; Watkins, 1992). 1996; Arendt, 2009. The possible causes of the abnormalities in slowed swimming decreased feeding, and decreased growth and development that we observed during our experiments are the mechanisms described above.

Egea-Serrano and Tejedo (2014) found that acute exposure to ammonium had no effect on swimming performance of $P$. perezi tadpoles from contaminated or undisturbed habitats. However, as described above, nitrateexposed animals are often lethargic as a possible result of reduced oxygen-carrying capacity (Gomez Isaza et al., 2018; Monsees et al., 2017). Lethargy can also increase susceptibility to predation (Scott and Sloman, 2004) 
According to the findings collected as a result of water quality analyzes and field observations, it was determined that Dryophytes suweonensis and Pelophylax chosenicus species, especially $D$. suweonensis, which lost its natural habitats as a result of the expansion of agricultural lands and had to live in these agricultural areas, chose places with low ammonium nitrate to live. Considering that ammonium nitrate is mainly caused by the application of chemical fertilizers in agricultural areas, it can be said that the reduction of these two endangered anuran species may be related to current agricultural practices (Borze et al., 2018). Similarly, when the relationship between water quality parameters and amphibian species richness in rivers under the effect of urbanization was evaluated with Habitat Model Affinity calculations, it was determined that species richness was negatively correlated with nitrate and phosphate concentrations, and positively correlated with high dissolved oxygen and conductivity (Calderon et al., 2019).

In the current study, mortality rates were especially high in the Mars frog and Variable Green toad, particularly in natural habitat larvae, while for the other species, the Iranian long-legged frog and Caucasian parsley frog, were similarly lower.

LC50 values, which express the concentration that causes the mortality of fifty percent of the populations, are among the most important parameter to be monitored within the scope of this experiment. Because if the lethal concentration is not known, it may not be possible to take protective measures accurately.

The upper limit of the nitrate concentration allowed in drinking or spring water are based on limited datasets (e.g., $\mathrm{LC}_{50}$ ) and is detected at $50 \mathrm{mg} / \mathrm{L} \mathrm{NO}_{3}$ (World Health Organization, 2018; TSE, 2005) These guidelines likely provide protection to some amphibians or other species but not all (Gomez Isaza et al., 2020). Furthermore, the LC $_{50}$ values (15 days old) detected for the different populations of the species examined were $37,46,59,74,111,155,170$, $204 \mathrm{mg} / \mathrm{L}$, from smallest to largest. As can be seen, there are some species with an $\mathrm{LC}_{50}$ value below this limit, and $50 \mathrm{mg} / \mathrm{L}$ is a concentration level that significant weight losses (average 59\%), abnormalities (average 30\%), mortalities (average 27\%) are seen for all populations and current abnormalities and weight lose can increase highly mortality risk for small and malformed tadpoles. Therefore, current protection measures need to be updated rapidly in order to protect biodiversity. Moreover, the survival of frogs, which undertake many beneficial tasks for the ecosystem in which they live and for human beings, is essential for the continuity of their species.

Consequently, based on all this information, it can be deduced that nitrogen compounds are the factors that negatively affect biodiversity, animal health, and environmental health in many different ways and ammonium generally has the most deleterious effects among nitrogenous ions on feeding, growth rate and, survival of living beings (Egea-Serrano et al., 2009; Ilha and Schiesari, 2014; Bellezi et al., 2015; Garriga et al., 2017). In this context, it is essential for the world's biodiversity and health that knowing the harmful and lethal concentrations has great importance in order to settle protective measures correctly. And furthermore, they must be carefully monitored in nature and their use must strictly regulate

\section{References}

Adum GB, Eichhorn MP, Oduro W, Ofori-Boateng C, R"odel MO. 2013. Two-stage recovery of amphibian assemblages following selective logging of tropical forests. Conserv. Biol., 27: 354-363.

Alford RA, Bradfield KS, Richards SJ. 2007. Global warming and amphibian losses. Nature, 447, E3-E4.

Badillo-Salda na LM, Ramírez-Bautista A, Wilson LD. 2016. Effects of establishment of grazing areas on diversity of amphibian communities in tropical evergreen forests and mountain cloud forests of the Sierra Madre Oriental. Rev. Mex. Biodivers., 87: 133-139.

Baker NJ, Bancroft BA, Garcia TS. 2013. A meta-analysis of the effects of pesticides and fertilizers on survival and growth of amphibians. Sci. Total Environ., 449: 150-156.

Barrett K, Guyer C. 2008. Differential responses of amphibians and reptiles in riparian and stream habitats to land use disturbances in western Georgia. USA. Biol. Conserv., 141: 2290-2300.

Beebee TJC, Griffiths RA. 2005. The amphibian decline crisis: a watershed for conservation biology? Biol. Conserv, 125: 271285.

Cano PD, Leynaud GC. 2010. Effects of fire and cattle grazing on amphibians and lizards in northeastern Argentina (Humid Chaco). Eur. J. Wildl. Res., 56: 411-420. https://doi.org/10.1007/s10344-009-0335-7.

Ceballos G, Ehrlich PR, Barnosky AD, García, A, Pringle RM, Palmer TM. 2015. Accelerated modern human-induced species losses: entering the sixth mass extinction. Sci. Adv. 1, e1400253

Cordier JM, Aguilar R, Lescano JN, Leynaud GC, Bonino A, Miloch D, Loyola R, Nori J. 2021. A global assessment of amphibian and reptile responses to land-use changes, Biological Conservation, 253: 1-10

Davidson NC. 2014. How much wetland has the world lost? Long-term and recent trends in global wetland area. Mar. Freshw. Res., 65: 934.

Egea-Serrano A, Relyea RA, Tejedo M, Torralva M. 2012. Understanding of the impact of chemicals on amphibians: a meta-analytic review. Ecol. Evol., 2: 1382-1397.

Falaschi M, Melotto A, Manenti R, Ficetola GF. 2020. Invasive species and amphibian conservation. Herpetologica, 76: 216227.

Flynn DFB, Gogol-Prokurat M, Nogeire T, Molinari N, Richers BT, Lin BB, Simpson N, Mayfield MM, DeClerck F. 2009. Loss of functional diversity under land use intensification across multiple taxa. Ecol. Lett., 12: 22-33.

Gagn'e SA, Fahrig L. 2007. Effect of landscape context on anuran communities in breeding ponds in the National Capital Region, Canada. Landsc. Ecol., 22: 205-215.

Gallant AL, Klaver RW, Casper GS, Lannoo MJ. 2007. Global rates of habitat loss and implications for amphibian conservation. Copeia 2007:967-979

Gallant AL, Klaver RW, Casper GS, Lannoo MJ. 2007. Global rates of habitat loss and implications for amphibian conservation. Copeia, 2007:967-979.

Gardner TA, Barlow J, Peres CA. 2007. Paradox, presumption and pitfalls in conservation biology: the importance of habitat change for amphibians and reptiles. Biol. Conserv., 138: 166179.

Guerra C, Ar'aoz E. 2015. Amphibian diversity increases in an heterogeneous agricultural landscape. Acta Oecol., 69: 78-86. https

Gültekin F, Dilek R, Firat Ersoy A, 2005. Ersoy H. Așağ1 Değirmendere (Trabzon) Havzasındaki Suların Kalitesi. Jeoloji Mühendisliği Dergisi, Haziran.

Gültekin, F, Ersoy AF, Hatipoğlu E., Celep S. 2012. Trabzon İli Akarsularının Yağışı Dönem Su Kalitesi Parametrelerinin Belirlenmesi. Ekoloji, Ocak 2012. 
Harfoot MBJ, Johnston A, Balmford A, Burgess ND, Butchart SHM, Dias MP, Hazin C, Hilton-Taylor C, et al. 2021. Using the IUCN Red List to map threats to terrestrial vertebrates at global scale. Nature Ecology \& Evolution.

Hodgkison SC, Hero JM, Warnken J. 2007. The conservation value of suburban golf courses in a rapidly urbanising region of Australia. Landsc. Urban Plan., 79: 323-337.

Hooke RLB, Martín-Duque JF, Pedraza J. 2012. Land transformation by humans: A review. GSA Today, 22: 4-10.

IUCN 2021. IUCN (International Union for Conservation of Nature and Natural Resources). https://www.iucnredlist.org/search?query=Amphibians\&sear chType $=$ species

IUCN, 2015. The IUCN Red List of Threatened Species. International Union for Conservation of Nature and Natural Resources. https://www. iucnredlist.org.

IUCN, 2020. The IUCN Red List of Threatened Species. International Union for Conservation of Nature and Natural Resources. https://www. iucnredlist.org.

Jantz P, Goetz S, Laporte N. 2014. Carbon stock corridors to mitigate climate change and promote biodiversity in the tropics. Nat. Clim. Chang., 4: 138-142.

Karaoglu H, Kutrup B, Ogut H. 2010. Intraspecific differences in responses of marsh frog (Pelophylax ridibundus) tadpoles exposed to environmentally relevant and acute levels of ammonium nitrate fertilizers. J. Freshw. Ecol., 25: 353-366.

Karaoglu, H., Amonyum nitrat suni gübresinin Kafkas Kurbağası (Pelodytes caucasicus) larvaları üzerindeki akut ve kronik etkileri, Doktora tezi, Karadeniz Teknik Üniversitesi, Fen Bilimleri Enstitüsü, Trabzon, 2011.

Krishnamurthy SV, Smith GR. 2010.Growth, abnormalities, and mortality of tadpoles of American toad exposed to combinations of malathion and nitrate. Environ Toxicol Chem., 29: 2777-2782.

Krishnamurthy SV, Smith GR. 2011.Combined effects of malathion and nitrate on early growth, abnormalities, and mortality of wood frog (Rana sylvatica) tadpoles. Ecotoxicol., 20: 1361-1367.

Kutt AS, Vanderduys EP, Ferguson D, Mathieson M. 2012. Effect of small-scale woodland clearing and thinning on vertebrate fauna in a largely intact tropical savanna mosaic. Wildl. Res., 39: 366.

Marco A, Ortiz-Santaliestra ME. 2009. Impact of reactive nitrogen on amphibians. In: Heatwole, H., Wilkinson, J.W. (Eds.), Amphibian Decline: Diseases, Parasites, Maladies and Pollution, vol. 8. Surrey Beatty \& Sons, Baulkham Hills, New South Wales, Australia. Amphibian Biology.

Mohsenipour M Shahid S, Ebrahimi K. 2014. Removal Techniques of Nitrate from Water, Asian Journal of Chemistry, November.

Newbold T, Hudson LN, Hill SLL, Contu S, Lysenko I, Senior RA, B"orger, L., Bennett DJ, Choimes A, Collen B, Day J, De Palma A, Díaz S, Echeverria- Londõno S, Edgar MJ, Feldman A, Garon M, Harrison MLK, Alhusseini T, Ingram DJ, Itescu Y, Kattge J, Kemp V, Kirkpatrick L, Kleyer M, Correia DLP, Martin CD, Meiri S, Novosolov M, Pan Y, Phillips HRP, Purve, DW, Robinson A, Simpson J, Tuck SL, Weiher E, White HJ, Ewers RM, Mace GM, Scharlemann JPW, Purvis A. 2015. Global effects of land use on local terrestrial biodiversity. Nature, 520: 45-50.

Nori J, Lemes P, Urbina-Cardona N, Baldo D, Lescano J, Loyola R. 2015. Amphibian conservation, land-use changes and protected areas: a global overview. Biol. Conserv., 191: 367374.

Orde nana MA, Crooks KR, Boydston EE, Fisher RN, Lyren LM, Siudyla S, Haas CD, Harris S, Hathaway SA, Turschak GM, Miles AK, Van Vuren DH. 2010. Effects of urbanization on carnivore species distribution and richness. J. Mammal., 91: $1322-1331$.
Özdemir A. 1998.Karadeniz Kıyı Şeridi Yüzeysel Sularında Nitrit, Nitrat, Amonyak, Toplam Kjeldahl Azotu Parametrelerinin İncelenmesi, Yüksek Lisans Tezi. Ondokuz Mayıs Üniversitesi, Fen Bilimleri Enstitüsü, Samsun, Türkiye,

Pimm SL, Jenkins CN, Abell R, Brooks TM, Gittleman JL, Joppa LN, Raven PH, Roberts CM, Sexton JO. 2014. The biodiversity of species and their rates of extinction, distribution, and protection. Science, 344: 6187.

Pimm SL, Raven P. 2000. Extinction by numbers. Nature, 403: 843-845.

Polat, H. 2018. Türkiye Tarım Topraklarının Verimlilik Özellikleri. TZOB, Çiftçi ve Köy Dünyası Dergisi, 33-37: Ankara,

Popescu VD, Patrick DA, Hunter ML, Calhoun AJK. 2012. The role of forest harvesting and subsequent vegetative regrowth in determining patterns of amphibian habitat use. For. Ecol. Manag., 270: 163-174.

Pounds JA, Bustamante MR, Coloma LA, Consuegra JA, Fogden MPL, Foster PN, La Marca E, Masters KL, Merino-Viteri A, Puschendorf R, Ron SR, S'anchez-Azofeifa GA, Still CJ, Young BE. 2006. Widespread amphibian extinctions from epidemic disease driven by global warming. Nature, 439: 161-167.

Roelants K, Gower DJ, Wilkinson M, Loader PS, Biju SD, Guillaume K, Moriau L, Bossuyt F. 2007. Global patterns of diversification in the history of modern amphibians. Pnas, 104,3: 887-892.

Sala OE, Chapin FS, Armesto JJ, Berlow E, Bloomfield J, Dirzo R, Huber- Sanwall E, Huenneke LF, Jackson RB, Kinzig A, Leemans R, Lodge DM, Mooney HA, Oesterheld M, Poff NL, Sykes MT, Walker B., Walker M, Wall DH. 2000. Global biodiversity scenarios for the year 2100. Science, 287: 17701774.

Scheffers BR, Paszkowski CA. 2013. Amphibian use of urban stormwater wetlands: the role of natural habitat features. Landsc. Urban Plan., 113: 139-149

Scott DM, Brown D, Mahood S, Denton B, Silburn A, Rakotondraparany F. 2006. The impacts of forest clearance on lizard, small mammal and bird communities in the arid spiny forest, southern Madagascar. Biol. Conserv., 127: 7287.

Shuman-Goodier ME, Singleton GR, Propper CR. 2017. Competition and pesticide exposure affect development of invasive (Rhinella marina) and native (Fejervarya vittigera) rice paddy amphibian larvae. Ecotoxicology, 26: 1293-1304.

Slaby S, Marin M, Marchand G, Lemiere S. 2019. Exposures to chemical contaminants: what can we learn from reproduction and development endpoints in the amphibian ecotoxicology literature? Environ. Pollut., 248: 478-495.

Sodhi NS, Bickford D, Diesmos AC, Lee TM, Koh LP, Brook BW, Sekerciogl, C H, Bradshaw CJA. 2008. Measuring the meltdown: drivers of global amphibian extinction and decline. PloS One 3, e1636.

Suazo-Ortũno I, Alvarado-Díaz J, Martínez-Ramos M. 2008. Effects of conversion of dry tropical forest to agricultural mosaic on herpetofaunal assemblages. Conserv. Biol., 22: 362-374.

Thompson ME, Nowakowski AJ, Donnelly MA. 2016. The importance of defining focal assemblages when evaluating amphibian and reptile responses to land use. Conserv. Biol., 30: 249-258.

Trudeau VL, Thomson P, Zhang WS, Reynaud S, NavarroMartín L, Langlois VS. 2020. Agrochemicals disrupt multiple endocrine axes in amphibians. Mol. Cell. Endocrinol. 513, 110861.

TSE266, Türk İçme Suyu Standartları TS 266 sayılı standart Türk Standartları Enstitüsü -Ankara, 2005. 
Van Meter RJ, Adelizzi R, Glinski DA, Henderson WM. 2019. Agrochemical mixtures and amphibians: the combined effects of pesticides and fertilizer on stress, acetylcholinesterase activity, and bioaccumulation in a terrestrial environment. Environ. Toxicol. Chem., 38: 10521061.
Wake DB, Vredenburg VT. 2008. Colloquium paper: are we in the midst of the sixth mass extinction? A view from the world of amphibians. Proc. Natl. Acad. Sci. U.S.A. 105 (Suppl), 11466-11473.

WHO, Guidelines for drinking-water quality. World Health Organization, Brazil, 2017. 